make it more difficult to implement NICE guidelines consistently. We feel that his concerns are at least equally applicable in $\mathrm{OOH}$ GP work.

\section{Simon Collins,}

Medical Director Medway On Call Care (MedOCC), Medway Community Healthcare.

E-mail: simoncollins1anhs.net

John Gration,

GP and Occupational Physician, Rochester, Kent.

\section{REFERENCES}

1. National Institute for Health and Care Excellence. Care of dying adults in the last days of life. NG31. London: NICE, 2015. https://www.nice.org.uk/ guidance/ng31 (accessed 3 Aug 2016).

2. Knights D. In defence of the 'tick-box approach': why end-of-life care is no exception. Br J Gen Pract 2016; DOI: 10.3399/bjgp16X685357. http://bjgp.org/ content/66/647/290

\section{Empathy, compassion, and kindness}

July's BJGP had articles on empathy, compassion, and kindness. ${ }^{1-3}$ In the same month I received an invitation to apply to join the interview panel for prospective medical students. The invitation says that these 17-year-olds are going to be assessed for their social awareness, caring ethos, and empathy. I wondered which of these unfortunates was going to be rejected for not feigning these attributes as convincingly as their competitors. And I wondered what sort of god-like creatures may exist among the pool of senior doctors who would be willing to dispense such judgements on the innocent. Perhaps none with any vestige of empathy, compassion, or kindness.

Chris Godwin,

GP, Blaenau, Gwent.

E-mail: chrislagwehelog.plus.com

\section{REFERENCES}

1. Austen L. Increasing emotional support for healthcare workers can rebalance clinical detachment and empathy. Br J Gen Pract 2016: DOI: 10.3399/bjgp16X685957. http://bjgp.org/ content/66/648/376.

2. Fernando AT, Arroll B, Consedine NS. Enhancing compassion in general practice: it's not all about the doctor. Br J Gen Pract 2016; DOI: 10.3399/ bjgp16X685741. http://bjgp.org/content/66/648/340.

3. Mathers N. Compassion and the science of kindness: Harvard Davis Lecture 2015. Br J Gen Pract 2016; DOI: 10.3399/bjgp16X686041. http://bjgp. org/content/66/648/e525

DOI: 10.3399/bjgp16X686785

\section{From Balint to square bashing}

Zigmond's article in the July BJGP is brilliant. ' It describes to us exactly how personal contact has been replaced by computers. Although I am retired, resent this modern intrusion. I have heard anecdotally of patients saying 'he constantly looks at the computer screen or 'she is typing on the keyboard, with her back turned from me, the patient. There is hardly any eye to eye contact! This continues after the patient has walked out of the surgery because the prescription has already been sent to the pharmacist electronically. This IT innovation has created a vacuum in the doctor-patient relationship. I had the privilege of attending Balint Seminars at the Tavistock Clinic, and I strongly believe in Balint's doctrine of that relationship. Zigmond rightly says in his article, ... we have replaced that human heart with a mechanical one that can count but cannot value'. It seems gone are the days of the adage 'Listen to the patient. They are giving you the diagnosis.' Instead of listening, talking, and looking at the patient we might as well click on Google to do the job.

Suresh Pathak,

Retired GP, Romford, Essex. E-mail: skpathak1371aaol.com

\section{REFERENCE}

1. Zigmond D. From Balint to square-bashing: 50 years' experience of general practice. Br J Gen Pract 2016; DOI 10.3399/bjgp16X685921. http://bjgp.org/ content/66/648/372.

DOI: 10.3399/bjgp16X686797 